\title{
Transmembrane Domain
}

National Cancer Institute

\section{Source}

National Cancer Institute. Transmembrane Domain. NCI Thesaurus. Code C13410.

The portion of an integral membrane protein crossing through the plasma lemma (cell

membrane) or that of an internal vesicle. This region is highly hydrophobic, approximately 20 amino acids long, and bordered by charged amino acids. 